\title{
Geriatric Anesthesia
}

Editors

ELIZABETH L. WHITLOCK

ROBERT A. WHITTINGTON

\section{ANESTHESIOLOGY CLINICS}

www.anesthesiology.theclinics.com

Consulting Editor

LEE A. FLEISHER

September 2019 • Volume 37 • Number 3 